\title{
MLL/SARNP Fusion Protein
}

National Cancer Institute

\section{Source}

National Cancer Institute. MLLISARNP Fusion Protein. NCI Thesaurus. Code C99354.

A fusion protein encoded by the MLL/SARNP fusion gene. This protein is comprised of the $\mathrm{N}$-terminal half of the histone-lysine $\mathrm{N}$-methyltransferase MLL protein, including the AT hook DNA binding domain and the DNA methyltransferase domain, fused to most of the SAP domain-containing ribonucleoprotein, including the SAP and nuclear localization domains. 